\title{
Transpiration efficiency of sorghum [Sorghum bicolor (L.) Moench] in relation to plant type and genotype
}

\author{
MRDL Kulathunga ${ }^{1 *}$, EJ van Oosterom ${ }^{2}$, GL Hammer ${ }^{2}$ and KS Deifel ${ }^{2}$ \\ ${ }^{I}$ Fruit Research and Development Institute, Kananwila, Horana. \\ ${ }^{2}$ Centre for Crop Science, Queensland Alliance for Agriculture and Food Innovation, The University of Queensland, Brisbane, QLD 4072, Australia.
}

\begin{abstract}
Sorghum is a major crop in dry land farming systems where grain yield is limited by water availability around anthesis. Genotypic differences in transpiration efficiency (TE) have been reported for sorghum, but it is unclear whether the TE of tall double dwarf (2d) genotypes is different to that of short triple dwarf (3d) ones. The objectives of this study are to determine whether (i) plant type in terms of plant stature has a significant effect on TE, and (ii) genotypic differences in TE are associated with leaf conductance or photosynthetic capacity. Individual plants of seven tall $2 \mathrm{~d}$ genotypes and 14 short $3 \mathrm{~d}$ genotypes were grown in lysimeters. Plants were well watered and harvested $5 \pm 1$ days after flowering of the main shoot. At harvest, total transpiration (T), leaf area and biomass were measured. TE, photosynthetic capacity and conductance were calculated. The TE did not differ between $2 \mathrm{~d}$ and $3 \mathrm{~d}$ plant types. Differences in TE among genotypes of both sorghum plant types were observed. These differences were associated with differences in photosynthetic capacity, rather than conductance and were not linked to stay-green expression. As stay-green expression can be a consequence of plant size, it indicates that $\mathrm{TE}$ and plant size are potentially independent traits of drought adaptation, highlighting the possibility of simultaneous selection for these two traits.
\end{abstract}

Keywords: Conductance, drought adaptation, photosynthetic capacity, plant stature, sorghum, transpiration efficiency.

\section{INTRODUCTION}

Sorghum is a major summer crop in rainfed farming systems around the world (Hammer et al., 2014; Geetika et al., 2019). In the grain belt of eastern Australia, it is the dominant dryland summer crop. Rainfall in sorghum cultivated areas of eastern Australia is highly variable (205 to $800 \mathrm{~mm}$ ). As a result, crops can experience a wide range of patterns of water supply during the growing season and timing and intensity of drought stress can be variable (Chapman et al., 2000).

Crop production in water limited environments is the product of total transpiration $(\mathrm{T})$, transpiration efficiency (TE) and harvest index (HI) (Passioura \& Angus, 2010). In this context, grain yield is linked to post anthesis transpiration or crop water used (Turner 2004; van Oosterom et al., 2011). Water stress at early reproductive phases can contribute to major yield losses (Borrell et al., 2014), because the crop growth rate, and in particular the panicle growth rate at anthesis determines grain number (Vega et al., 2001; Andrade et al., 2002; van Oosterom \& Hammer, 2008). Tall 2d sorghum tends to have greater grain yield than short $3 \mathrm{~d}$ sorghum, but this is predominantly associated with increased grain mass, rather than grain number (George-Jaeggli et al., 2011). Within the above framework, grain yield can be increased by restricting pre-anthesis water use to maximise post anthesis water availability (Hammer, 2006). Simulation studies for wheat (Triticum aestivum L.) indicated a yield increase of $50-60 \mathrm{~kg} / \mathrm{ha}$ per millimetre of extra water uptake after anthesis (Manschadi et al., 2006). Crops that have higher potential biomass production prior to anthesis utilise more water and as a consequence have less soil water available for reproductive growth

\footnotetext{
* Corresponding author (rdkulathunga@gmail.com; (iD https://orcid.org/0000-0001-6087-2191)
} 
(Hammer, 2006; van Oosterom et al., 2011). Hence, under water limited conditions, increased post anthesis transpiration as a fraction of total transpiration could be an important aspect of drought stress.

As a tillering crop, plant size of sorghum can be reduced by restricting tillering (Hammer et al., 1997). Tillering is associated with the carbon supply/demand balance of the crop (Kim et al., 2010). However, in environment $\times$ management conditions that are not conducive to tillering, such as high plant density and high temperatures (Kim et al., 2010), water saving through reduced tillering has limited value for rainfed farming systems. Under such conditions, TE and its components become more important factors of drought adaptation in breeding programmes (Blum, 2009; Lobell et al., 2014). Within the context of growth rates around anthesis, increased TE can delay the onset of drought stress if it is associated with reduced water use, or increase the growth rate for the same water use. Both mechanisms can potentially increase the crop growth rate around anthesis, and hence the panicle growth rate and therefore grain number. Genotypic differences in TE have been reported for sorghum (Hammer et al., 1997; Balota et al., 2008; Xin et al., 2009), but little information is available on the crop physiological mechanisms that determine these differences and whether $2 \mathrm{~d}$ and $3 \mathrm{~d}$ sorghum differ in TE. The genotypic variation for TE in sorghum could be associated with differences in photosynthetic capacity (Hammer et al., 1997; Xin et al., 2009), conductance (Mortlock \& Hammer, 1999), or leakage of $\mathrm{CO}_{2}$ to the bundle sheath (Henderson et al., 1998). At the leaf level, TE is the ratio of photosynthetic capacity and conductance (Polley et al., 1996). At the plant level, photosynthetic capacity can be estimated as biomass production per unit leaf area and conductance as transpiration per unit leaf area. Therefore, an experiment was conducted to measure TE and associated parameters of photosynthetic capacity and conductance at the plant level for a range of tall double dwarf (2d) and short triple dwarf (3d) sorghum genotypes. The aims of this study were to determine if sorghum plant types differ in TE, and if so, whether there is any genotypic differences in TE associated with plant stature or with components of TE (conductance or photosynthetic capacity).

\section{METHODOLOGY}

\section{Experimental details}

The experiment was conducted in a semi controlled lysimetery facility in a shade house at Gatton $\left(27^{\circ} 33^{\prime} \mathrm{S}\right.$, $\left.152^{\circ} 20^{\prime} \mathrm{E}\right)$, Queensland, Australia. It included seven double dwarf (2d) and 14 triple dwarf (3d) sorghum genotypes. The genotypes contained two hybrids, whereas the remainder were inbred lines that represented a diverse range of germplasm, including parents of mapping populations and elite breeding lines (Table 1). The experimental design was a modified split plot with plant type (2d sorghum, 3d sorghum) as main plots and genotypes as subplots. The experiment had four replications and a blank reference pot was included in each $2 \mathrm{~d}$ sorghum main plot.

Genotypes were grown as individual plants in lysimeters. Lysimeters had a size of around 51 litres, which did not restrict root growth (Yang et al., 2010). Prior to filling, each pot was lined with a plastic bag to facilitate removal of the soil at harvest. The pots were filled with air dried soil to a weight of $61 \mathrm{~kg}$. Approximately $42 \mathrm{~g}$ of Osmocote plus $(16 \% \mathrm{~N}, 3.5 \% \mathrm{P}$, $10 \% \mathrm{~K}$ ) slow releasing fertilizer and $40 \mathrm{~g}$ of dolomite (to minimise symptoms of calcium deficiency) were added to each pot in six evenly distributed layers during soil filling. After filling, pots were watered up to slightly below the drained upper limit (DUL) or field capacity. The DUL was determined from a reference pot that had holes drilled in the bottom and was filled with the same amount of soil but without plastic liner. The pot was watered, and left to drain, and the amount of water to be added to the experimental pots was determined from the difference in weight before watering and after draining. As the soil in each lysimeter compacted during watering, an additional $8 \mathrm{~kg}$ of soil was added to each pot and water was added pro rata to achieve the DUL.

Five seeds were planted in the middle of each pot, and after emergence, these were gradually thinned until one plant per pot was left when two to three leaves had fully expanded. At that stage, the soil surface of each lysimeter was covered and sealed with thick plastic to minimise soil evaporation. Each lysimeter pot was placed on its own load cell, and weight was recorded automatically every $15 \mathrm{~min}$. Once the pot weight dropped below a preset value (around $1.5 \mathrm{~kg}$ below DUL) $500 \mathrm{~mL}$ of water was automatically added. Hence, water content of soil in the containers was maintained above the lower limit (LL) or wilting point. Pots were thus watered as required, and plant available water was maintained at a level at which drought stress did not occur, but was slightly below DUL to minimise the risk of water logging. If the fraction of available soil water is higher than 0.3 , the transpiration rate is not changed (Sinclair \& Ludlow, 1986). Therefore, addition of $500 \mathrm{~mL}$ of water could maintain the plant without water deficit. Water was added through a porous plastic tube ( $2 \mathrm{~cm}$ diameter) that was buried down to a 
depth of $10 \mathrm{~cm}$ above the base of pots. Hence, water could be absorbed into soil and capillary action could help to move water up to the root zone of plants. As sorghum is sensitive to calcium (Ca) deficiency, a solution of
$0.3 \% \mathrm{Ca}\left(\mathrm{NO}_{3}\right)_{2}$ was sprayed into the whorl of each axis at daily intervals to minimize $\mathrm{Ca}$ deficiency symptoms. Nonetheless, one plant showed severe symptoms of $\mathrm{Ca}$ deficiency and had to be discarded.

Table 1: Name, origin, and characteristics of the sorghum genotypes used in the experiment

\begin{tabular}{|c|c|c|}
\hline Name & Origin & Characteristics \\
\hline \multicolumn{3}{|l|}{$2 \mathrm{~d}$ sorghum } \\
\hline $\mathrm{Ai} 4$ & China & 2-dwarf, photoperiod insensitive, possible cold tolerance \\
\hline IS 8525 & Ethiopia & Early flowering parent of mapping population for ergot resistance \\
\hline IS9710 & Sudan & High TE line (Hammer et al., 1997) \\
\hline PI291382 & China & Shatter cane line with high TE (Xin et al., 2009) \\
\hline PI391652 & China & High TE line (Xin et al., 2009) \\
\hline PI584085 & Uganda & Caudatum line with high TE (Xin et al., 2009) \\
\hline PI656046 & China & Durra line with high TE \\
\hline \multicolumn{3}{|l|}{$3 \mathrm{~d}$ sorghum } \\
\hline A1*FB963676/R931945 (hybrid) & Australia & Hybrid of two lines included in the experiment \\
\hline BТх642 & Ethiopia & Highly stay-green, low tillering, partially converted durra landrace. \\
\hline B923296 & Australia & Elite stay-green, heat sensitive, narrow root angle parent DFAF breeding program \\
\hline B963676 & Australia & Good heat tolerance, wide root angle, widely used commercial female. \\
\hline MR Buster (hybrid) & Australia & High-tillering standard commercial check hybrid \\
\hline QL12 & Australia & Early flowering source of stay-green drought resistance \\
\hline R9188 & USA & Partially converted derivative of sweet sorghum Rio \\
\hline R931945-2-2 & Australia & Elite low-tillering stay-green parent DFAF breeding program \\
\hline R9403463-2-1 & Australia & Elite moderately senescent parent DFAF breeding program \\
\hline SC170-6-8 & Ethiopia & High tillering, heat sensitive, wide root angle, partly converted caudatum line \\
\hline $\mathrm{SC} 237-14 \mathrm{E}$ & Sudan & Caudatum line with high TE (Hammer et al., 1997) \\
\hline TAM422 & USA & Early hybrid parent lacking in stay-green drought resistance \\
\hline $\mathrm{Tx} 430$ & USA & Yellow endosperm. Widely used as parent commercially in the USA \\
\hline Tx7000 & USA & Early hybrid parent lacking in stay-green drought resistance \\
\hline
\end{tabular}

\section{Observations and measurements}

The number of visible fully expanded, and senesced leaves on the main shoot and all tillers of every plant were counted twice a week. A leaf was counted as visible leaf when its tip was visible inside the whorl of the previous leaf, as fully expanded leaf when its ligule was visible above the ligule of the previous leaf, and as senesced leaf when $>50 \%$ of its lamina had died. Tillers were labelled according to leaf axil from which they appeared. For example, tiller 3 (T3) appeared from the axil of leaf 3. The length and maximum width of each fully expanded leaf were measured non-destructively on all plants. Leaf area of each leaf was estimated from the measured length and width, multiplied by a scaling factor of $0.71(0.635$ for flag leaves) (van Oosterom et al., 2011).
Daily transpiration per plant was calculated as the decline in pot weight for that day, plus any water added. Transpiration throughout the season was calculated as the sum of these daily values, adjusted for the fresh shoot mass at harvest, dry root mass at harvest, and any change in weight of the empty reference pots.

Plants were harvested 5 days after $50 \%$ of anthers in the main shoot panicle were visible. Plants were cut below the base of the stem and shoot fresh weight was determined (after removal of soil). Roots of each plant were washed thoroughly until all the debris and soil particles were removed. Shoot and root dry masses of each plant were determined after drying in a dehydrator at $60{ }^{\circ} \mathrm{C}$ for $48 \mathrm{~h}$. 
TE was calculated as the ratio of biomass and seasonal transpiration using only shoot biomass (TE_shoot) or using both shoot and root biomass (TE_total). The two components of TE; photosynthetic capacity and conductance, which at the plant level, can be represented by biomass per unit leaf area (B/LA) and transpiration per unit leaf area (T/LA), respectively were calculated.

Data were analysed in SAS v.9.3. using the General Linear Model (GLM) procedure for ANOVAs and means separated using Duncan's multiple range test for genotypic differences.

Table 2: ANOVA of plant type and genotypic differences in phenology, total biomass, and leaf area

\begin{tabular}{|c|c|c|c|c|c|}
\hline \multirow{2}{*}{$\begin{array}{l}\text { Plant type } \\
\text { 2d sorghum }\end{array}$} & \multirow{2}{*}{$\begin{array}{l}\text { Days to } \\
\text { flowering }\end{array}$} & \multicolumn{2}{|c|}{ Biomass $\left(\right.$ g plant $\left.^{-1}\right)$} & \multicolumn{2}{|c|}{ Leaf area $\left(\mathrm{m}^{2}\right.$ plant $\left.^{-1}\right)$} \\
\hline & & & $152.61 \mathrm{~b}$ & & $0.591 \mathrm{~b}$ \\
\hline $3 \mathrm{~d}$ sorghum & $74.6 \mathrm{a}$ & & $193.54 \mathrm{a}$ & & $0.850 \mathrm{a}$ \\
\hline $\mathrm{CV}$ & 3.68 & & 17.45 & & 16.48 \\
\hline Probability block & 0.0262 & & 0.4258 & & 0.57 \\
\hline Probability species & $<0.0001$ & & $<0.0001$ & & $<0.0001$ \\
\hline Probability genotype & $<0.0001$ & & $<0.0001$ & & $<0.0001$ \\
\hline \multicolumn{6}{|l|}{$2 \mathrm{~d}$ sorghum } \\
\hline IS9710 & 75.0 efg & IS9710 & $264.00 \mathrm{~b}$ & IS9710 & $0.960 \mathrm{bcd}$ \\
\hline $\mathrm{Ai} 4$ & $69.5 \mathrm{ij}$ & PI584085 & 187.49 defg & PI584085 & $0.807 \mathrm{def}$ \\
\hline PI656046 & $69.3 \mathrm{ij}$ & PI656046 & $179.58 \mathrm{efgh}$ & PI656046 & 0.696 fghi \\
\hline PI584085 & $58.3 \mathrm{kl}$ & $\mathrm{Ai} 4$ & 142.46 ghi & IS 8525 & $0.511 \mathrm{ij}$ \\
\hline PI391652 & $58.3 \mathrm{kl}$ & PI391652 & $131.52 \mathrm{hi}$ & $\mathrm{Ai} 4$ & $0.479 \mathrm{j}$ \\
\hline IS8525 & 54.51 & IS 8525 & $113.95 \mathrm{i}$ & PI391652 & $0.455 \mathrm{j}$ \\
\hline PI291382 & $45.8 \mathrm{~m}$ & PI291382 & $49.28 \mathrm{j}$ & PI291382 & $0.226 \mathrm{k}$ \\
\hline \multicolumn{6}{|l|}{$3 \mathrm{~d}$ sorghum } \\
\hline R931945-2-2 & $86.5 \mathrm{a}$ & Tx430 & $327.59 \mathrm{a}$ & Tx430 & $1.600 \mathrm{a}$ \\
\hline R9403463-2-1 & $85.3 \mathrm{ab}$ & SC170-6-8 & $260.00 \mathrm{~b}$ & SC170-6-8 & $1.138 \mathrm{~b}$ \\
\hline SC170-6-8 & $82.0 \mathrm{bc}$ & $\begin{array}{l}\text { A1*FB963676/ } \\
\text { R931945 }\end{array}$ & $246.81 \mathrm{bc}$ & SC237-14E & $1.082 \mathrm{bc}$ \\
\hline $\mathrm{Tx} 430$ & $80.0 \mathrm{~cd}$ & SC237-14E & $236.27 \mathrm{bcd}$ & R9403463-2-1 & $0.956 \mathrm{bcd}$ \\
\hline $\begin{array}{l}\text { A1*FB963676/ } \\
\text { R931945 }\end{array}$ & $77.3 \mathrm{de}$ & R931945-2-2 & 220.25 bcde & Tx7000 & $0.923 \mathrm{cde}$ \\
\hline SC237-14E & $75.8 \mathrm{ef}$ & R9403463-2-1 & 204.24 cde & $\begin{array}{l}\text { A1*FB963676/ } \\
\text { R931945 }\end{array}$ & 0.914 cde \\
\hline B35 & $74.3 \mathrm{efgh}$ & B923296 & $198.23 \mathrm{cdef}$ & R931945-2-2 & $0.851 \mathrm{def}$ \\
\hline B923296 & $74.3 \mathrm{efgh}$ & B963676 & 189.70 defg & B923296 & $0.759 \mathrm{defg}$ \\
\hline QL12 & 73.0 fghi & Tx7000 & 182.71 efg & B963676 & $0.736 \mathrm{efgh}$ \\
\hline B963676 & 71.5 ghij & Buster & 152.82 fghi & Buster & 0.700 fghi \\
\hline Tx7000 & $70.5 \mathrm{hij}$ & B35 & $126.33 \mathrm{i}$ & B35 & 0.583 ghij \\
\hline TAM422 & $67.8 \mathrm{j}$ & QL12 & $115.25 \mathrm{i}$ & TAM422 & 0.559 ghij \\
\hline R9188 & $62.0 \mathrm{k}$ & TAM422 & $114.63 \mathrm{i}$ & R9188 & 0.537 hij \\
\hline Buster & $61.8 \mathrm{k}$ & R9188 & $114.14 \mathrm{i}$ & QL12 & $0.493 \mathrm{ij}$ \\
\hline
\end{tabular}




\section{RESULTS AND DISCUSSION}

\section{Phenotypic characters}

Time to flowering was significantly different among plant types (Table 2) and genotypes within each plant type. $2 \mathrm{~d}$ sorghum flowered earlier than $3 \mathrm{~d}$ sorghum. The late flowering of $3 \mathrm{~d}$ sorghum was associated with low temperatures around flowering in late autumn - early winter, in particular some of the $3 \mathrm{~d}$ sorghum genotypes (Table 2).
$2 \mathrm{~d}$ sorghum on average produced significantly less biomass and leaf area per plant than $3 \mathrm{~d}$ sorghum (Tables 2 and 3). This was associated with the faster growth in $2 \mathrm{~d}$ sorghum, and their lower leaf number on the main shoot, while the productive tiller number was similar in both plant types (Table 3). Biomass production and leaf area also differed significantly among genotypes, partly because of the differences in anthesis date and hence harvest date. However, some $3 \mathrm{~d}$ genotypes produced similar biomass to that of $2 \mathrm{~d}$ sorghum (Table 2).

Table 3: ANOVA on plant differences in plant height, tiller number, and main shoot dry mass allocation to the stem (height excludes panicle and is stem only)

\begin{tabular}{lllll}
\hline & $\begin{array}{l}\text { Total leaf } \\
\text { number }\end{array}$ & $\begin{array}{l}\text { Plant height } \\
(\mathrm{cm})\end{array}$ & $\begin{array}{l}\text { Productive tiller } \\
\text { number }\end{array}$ & $\begin{array}{l}\text { Main shoot dry } \\
\text { mass to stem }(\%)\end{array}$ \\
\hline 2d sorghum & $12.18 \mathrm{~b}$ & $169.36 \mathrm{a}$ & $3.00 \mathrm{a}$ & $62.67 \mathrm{a}$ \\
3d sorghum & $14.76 \mathrm{a}$ & $78.43 \mathrm{~b}$ & $3.05 \mathrm{a}$ & $44.63 \mathrm{~b}$ \\
\hline
\end{tabular}

Values within a column followed by the same letters are not significantly different at the $5 \%$ level according to Duncan multiple range test

Plant type differences in shoot and root mass were generally consistent with differences in total biomass (Table 4). The relatively high coefficient of variation (CV) for shoot mass (18\%) was most likely a consequence of differences in tillering among individual plants across replications. The CV for root mass (26.57) was approximately $50 \%$ greater than for shoot mass, suggesting an acceptable level of accuracy for root mass. Dry matter partitioning to roots (Table 4) showed significant differences among plant types, with root/ shoot ratio of $2 \mathrm{~d}$ sorghum significantly lower than for $3 \mathrm{~d}$ sorghum (Table 4).

Within plant types, significant genotypic differences were observed in root mass, shoot mass and root/shoot ratio (Table 4). Nonetheless, genotypic variation in root/ shoot ratio was generally small. The main exceptions were 3d sorghum genotypes R931945-2-2 and QL12, as both had high root/shoot ratio. Both these genotypes were low-tillering (Table 2).

\section{Transpiration and transpiration efficiency}

Plant type differences in seasonal transpiration (Table 5) to a large extent reflected differences in phenotypic characters and hence plant size at harvest. Transpiration was significantly greater in $3 \mathrm{~d}$ than in $2 \mathrm{~d}$ sorghum. Genotypes of both $3 \mathrm{~d}$ and $2 \mathrm{~d}$ sorghum showed significant differences in transpiration (Table 5). Genotype Tx430 (3d), which flowered relatively late had the highest transpiration and the early flowering genotype PI291382 (2d) the lowest.

Both situations of TE_shoot and TE_(total) in $2 \mathrm{~d}$ and $3 \mathrm{~d}$ sorghum showed similar TE (Table 6). Hence, TE was not associated with plant stature. However, there were significant genotypic differences in TE, and the values ranged from $7.7-10.3 \mathrm{~g} \mathrm{~kg}^{-1}$ for TE shoot and from 9.2-11.2 $\mathrm{g} \mathrm{kg}^{-1}$ for TE_(total) (Table 6). Among 2d genotypes, PI656046 had the highest TE_(total) $\left(11.2 \mathrm{~g} \mathrm{~kg}^{-1}\right)$ and it was significantly greater than that of Ai4, IS8525 and PI291382, which had the lowest TE_(total) (9.5-9.6 $\left.\mathrm{g} \mathrm{kg}^{-1}\right)$. PI584085, PI391652, and IS9710 were intermediate $\left(10.2-10.6 \mathrm{~g} \mathrm{~kg}^{-1}\right)$. Differences were comparable for TE_shoot. Among 3d genotypes, A1*FB963676/R931945, B923296 and B963676 had the highest TE_(total) $\left(10.8-10.9 \mathrm{~g} \mathrm{~kg}^{-1}\right)$ and for the first two, the TE_(total) was significantly greater than Tx7000, QL12 and Tx430 (9.2-9.4 $\left.\mathrm{g} \mathrm{kg}^{-1}\right)$. Same trend was observed for TE_shoot. 
Table 4: ANOVA of plant type and genotypic differences in shoot mass, root mass, and root/shoot ratio.

\begin{tabular}{|c|c|c|c|c|c|}
\hline \multirow{2}{*}{$\begin{array}{l}\text { Plant type } \\
\text { 2d sorghum }\end{array}$} & \multirow{2}{*}{$\begin{array}{c}\text { Shoot mass } \\
\left(\text { g plant }^{-1}\right)\end{array}$} & \multicolumn{2}{|c|}{ Root mass (g plant ${ }^{-1}$ ) } & \multicolumn{2}{|c|}{ Root/Shoot ratio } \\
\hline & & & $11.95 \mathrm{~b}$ & & $0.087 \mathrm{~b}$ \\
\hline $3 \mathrm{~d}$ sorghum & $173.7 \mathrm{a}$ & & $19.81 \mathrm{a}$ & & $0.117 \mathrm{a}$ \\
\hline $\mathrm{CV}$ & 18 & & 26.57 & & 20.83 \\
\hline Probability block & 0.5531 & & 0.1362 & & 0.6135 \\
\hline Probability species & $<0.0001$ & & $<0.0001$ & & $<0.0001$ \\
\hline Probability genotype & $<0.0001$ & & $<0.0001$ & & $<0.0001$ \\
\hline \multicolumn{6}{|l|}{ orghum } \\
\hline IS9710 & $241.5 \mathrm{~b}$ & IS9710 & $22.51 \mathrm{bc}$ & IS9710 & $0.095 \mathrm{cdef}$ \\
\hline PI584085 & $175.8 \mathrm{cdef}$ & PI656046 & $14.02 \mathrm{defg}$ & $\mathrm{Ai} 4$ & 0.092 cdef \\
\hline PI656046 & $165.6 \mathrm{defg}$ & $\mathrm{Ai} 4$ & $11.89 \mathrm{efgh}$ & IS 8525 & $0.091 \mathrm{def}$ \\
\hline $\mathrm{Ai} 4$ & $130.6 \mathrm{fgh}$ & PI584085 & $11.73 \mathrm{efgh}$ & PI291382 & $0.091 \mathrm{cdef}$ \\
\hline PI391652 & $122.2 \mathrm{gh}$ & IS 8525 & $9.42 \mathrm{gh}$ & PI656046 & $0.085 \mathrm{def}$ \\
\hline IS 8525 & $104.5 \mathrm{~h}$ & PI391652 & $9.34 \mathrm{gh}$ & PI391652 & $0.077 \mathrm{def}$ \\
\hline PI291382 & $44.5 \mathrm{i}$ & PI291382 & $4.75 \mathrm{~h}$ & PI584085 & $0.068 \mathrm{f}$ \\
\hline \multicolumn{6}{|l|}{$3 \mathrm{~d}$ sorghum } \\
\hline $\mathrm{Tx} 430$ & $295.3 \mathrm{a}$ & R931945-2-2 & $35.33 \mathrm{a}$ & R931945-2-2 & $0.190 \mathrm{a}$ \\
\hline SC170-6-8 & $236.5 \mathrm{~b}$ & $\mathrm{~T} \times 430$ & $32.30 \mathrm{a}$ & QL12 & $0.190 \mathrm{a}$ \\
\hline A1*FB963676/R931945 & $222.0 \mathrm{bc}$ & A1*FB963676/R931945 & $24.79 \mathrm{~b}$ & R9403463-2-1 & $0.137 \mathrm{~b}$ \\
\hline SC237-14E & $220.6 \mathrm{bc}$ & R9403463-2-1 & $24.75 \mathrm{~b}$ & Buster & $0.128 \mathrm{bc}$ \\
\hline R931945-2-2 & $184.9 \mathrm{~cd}$ & SC170-6-8 & $24.25 \mathrm{~b}$ & B35 & $0.126 b c$ \\
\hline R9403463-2-1 & $179.5 \mathrm{cde}$ & B923296 & 19.96 bcde & A1*FB963676/R931945 & $0.113 \mathrm{bcd}$ \\
\hline B923296 & $178.3 \mathrm{cdef}$ & QL12 & 18.22 bcdef & $\mathrm{Tx} 430$ & $0.110 \mathrm{bcd}$ \\
\hline B963676 & $177.5 \mathrm{cdef}$ & Buster & 17.38 bcdefg & B923296 & 0.108 bcde \\
\hline Tx7000 & $166.1 \mathrm{defg}$ & Tx7000 & $16.61 \mathrm{bcdefg}$ & SC170-6-8 & 0.104 bcdef \\
\hline Buster & 135.4 efgh & SC237-14E & 15.64 cdefg & Tx7000 & 0.101 bcdef \\
\hline B35 & $112.6 \mathrm{~h}$ & B35 & $13.72 \mathrm{defg}$ & TAM422 & $0.094 \mathrm{cdef}$ \\
\hline QL12 & $104.8 \mathrm{~h}$ & B963676 & $12.20 \mathrm{efgh}$ & R9188 & $0.094 \mathrm{cdef}$ \\
\hline TAM422 & $104.1 \mathrm{~h}$ & R9188 & $10.01 \mathrm{fgh}$ & SC237-14E & 0.071 ef \\
\hline R9188 & $97.0 \mathrm{~h}$ & TAM422 & $9.82 \mathrm{fgh}$ & B963676 & 0.070 ef \\
\hline
\end{tabular}

Values within a column followed by the same letters are not significantly different at the $5 \%$ level according to Duncan multiple range test

\section{Components of TE: photosynthetic capacity and conductance}

Plant types showed significant differences in both photosynthetic capacity and conductance, with $2 \mathrm{~d}$ sorghum on average having significantly greater values than $3 \mathrm{~d}$ sorghum (Table 7). These differences represented the increased allocation of dry mass to stem in taller $2 \mathrm{~d}$ sorghum (Table 3 ).
Across genotypes, the association between TE_(total) and either photosynthetic capacity (Figure 1) or conductance (Figure 2) varied. In general, TE_shoot was positively associated with photosynthetic capacity $\left(\mathrm{R}^{2}=0.43\right.$, $\mathrm{p}<0.01$ ), Figure 1), except for Ai4 (2d), which had low TE_(total) despite having the highest photosynthetic capacity. This was because of an extremely high conductance for Ai4 (Table 7, Figure 2). Similarly, the low TE_(total) of QL12 (3d) was associated with 
Table 5: ANOVA of plant type and genotypic differences in total transpiration

\begin{tabular}{|c|c|}
\hline Plant type & Total Transpiration $(\mathrm{kg})$ \\
\hline $2 \mathrm{~d}$ sorghum & $14.60 \mathrm{~b}$ \\
\hline $3 \mathrm{~d}$ sorghum & $18.71 \mathrm{a}$ \\
\hline $\mathrm{CV}$ & 21.88 \\
\hline Probability block & 0.4575 \\
\hline Probability species & $<0.0001$ \\
\hline Probability genotype & $<0.0001$ \\
\hline \multicolumn{2}{|l|}{$2 \mathrm{~d}$ sorghum } \\
\hline IS9710 & $24.33 \mathrm{~b}$ \\
\hline PI584085 & $17.59 \mathrm{cdef}$ \\
\hline PI656046 & $16.39 \mathrm{cdef}$ \\
\hline $\mathrm{Ai} 4$ & $14.89 \mathrm{def}$ \\
\hline PI391652 & $12.46 \mathrm{ef}$ \\
\hline IS8525 & $11.51 \mathrm{f}$ \\
\hline PI291382 & $5.11 \mathrm{~g}$ \\
\hline \multicolumn{2}{|l|}{$3 \mathrm{~d}$ sorghum } \\
\hline $\mathrm{T} \times 430$ & $34.3 \mathrm{a}$ \\
\hline SC170-6-8 & $24.81 \mathrm{~b}$ \\
\hline SC237-14E & $21.95 \mathrm{bc}$ \\
\hline A1*FB963676/ & $21.75 \mathrm{bc}$ \\
\hline \multicolumn{2}{|l|}{ R931945 } \\
\hline R931945-2-2 & $21.64 \mathrm{bc}$ \\
\hline R9403463-2-1 & $19.93 \mathrm{bcd}$ \\
\hline Tx7000 & 18.72 bcde \\
\hline B923296 & $17.54 \mathrm{cdef}$ \\
\hline B963676 & $17.21 \mathrm{cdef}$ \\
\hline Buster & $14.21 \mathrm{def}$ \\
\hline B35 & $12.89 \mathrm{ef}$ \\
\hline QL12 & $12.34 \mathrm{f}$ \\
\hline TAM422 & $11.61 \mathrm{f}$ \\
\hline R9188 & $11.19 \mathrm{f}$ \\
\hline
\end{tabular}

Values within a column followed by the same letters are not significantly different at the $5 \%$ level according to Duncan multiple range test

high conductance. In general, there was no association between TE_(total) and conductance (Figure 2).

\section{Effect of genotypes on TE}

TE_(total) ranged from 9.2-11.2 $\mathrm{g} \mathrm{kg}^{-1}$ across sorghum genotypes. The observed TE was slightly greater than the standard TE of $9 \mathrm{~g} \mathrm{~kg}^{-1}$ for sorghum (Tanner \&

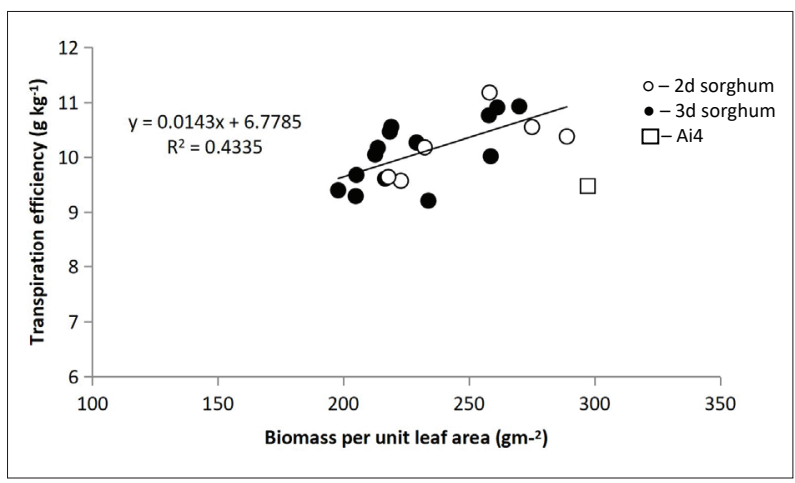

Figure 1: Biomass per unit leaf area vs transpiration efficiency (shoot+root)

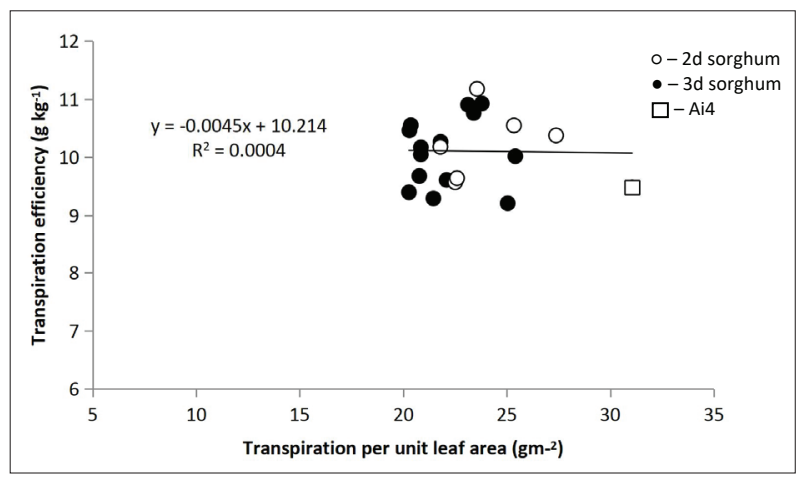

Figure 2: Transpiration efficiency (shoot+root) vs transpiration per unit leaf area

Sinclair, 1983) and could be due to low vapour pressure deficit (VPD) during autumn towards the end of the experiment, when plant size was highest. In addition, the higher values may reflect the increase in atmospheric $\mathrm{CO}_{2}$ concentration over the past 30 years (Forster \& Ramaswamy, 2007), as TE increases with increasing atmospheric $\mathrm{CO}_{2}$ levels (Eamus, 1991). The two 3d hybrids (AI*FB963976/R931945 and Buster) showed above average TE that was not significantly different to that of PI656046, the genotype with the highest TE (Table 6). In addition, TE_(total) of A1*FB963676/ R931945 (10.92 $\left.\mathrm{g} \mathrm{kg}^{-1}\right)$ was similar to that of B963676 and R931945-2-2, which were $10.76 \mathrm{~g} \mathrm{~kg}^{-1}$ and $10.02 \mathrm{~g}$ $\mathrm{kg}^{-1}$, respectively (Table 3.6), whereas Xin et al. (2009) reported that the TE of ATx623/RTx430 $\left(7.9 \mathrm{~g} \mathrm{~kg}^{-1}\right)$ was intermediate between that of its two parents BTx623 $\left(8.1 \mathrm{~g} \mathrm{~kg}^{-1}\right)$ and RTx430 $\left(7.8 \mathrm{~g} \mathrm{~kg}^{-1}\right)$. There is thus no evidence to suggest that differences in TE are associated with differences between inbred lines and hybrids. 
Table 6: ANOVA of plant type and genotypic differences in transpiration efficiency for shoot biomass (TE_shoot) and total biomass (TE_Total)

\begin{tabular}{|c|c|c|c|}
\hline \multirow{2}{*}{$\begin{array}{l}\text { Plant type } \\
\text { 2d sorghum }\end{array}$} & \multirow{2}{*}{$\begin{array}{c}\text { TE_shoot } \\
\text { biomass }(\mathrm{g} / \mathrm{kg})\end{array}$} & \multicolumn{2}{|c|}{ TE_Total biomass $(\mathrm{g} / \mathrm{kg})$} \\
\hline & & & $10.14 \mathrm{a}$ \\
\hline $3 \mathrm{~d}$ sorghum & $9.05 \mathrm{a}$ & & $10.09 \mathrm{a}$ \\
\hline $\mathrm{CV}$ & 8.11 & & 7.9 \\
\hline Probability block & 0.0019 & & 0.0008 \\
\hline Probability species & $<0.0001$ & & $<0.0001$ \\
\hline Probability genotype & $<0.0001$ & & $<0.0001$ \\
\hline \multicolumn{4}{|l|}{$2 \mathrm{~d}$ sorghum } \\
\hline PI656046 & $10.30 \mathrm{a}$ & PI656046 & $11.18 \mathrm{a}$ \\
\hline IS9710 & 9.63 abcdef & IS9710 & $10.55 \mathrm{abcd}$ \\
\hline PI391652 & 9.63 abcdef & PI391652 & $10.38 \mathrm{abcd}$ \\
\hline PI584085 & 9.54 abcdef & PI584085 & $10.18 \mathrm{abcd}$ \\
\hline IS 8525 & $8.77 \mathrm{cdefg}$ & PI291382 & $9.64 \mathrm{bcd}$ \\
\hline PI291382 & 8.68 cdefg & IS 8525 & $9.57 \mathrm{bcd}$ \\
\hline Ai4 & 8.67 cdefg & Ai4 & $9.48 \mathrm{~cd}$ \\
\hline \multicolumn{4}{|l|}{$3 \mathrm{~d}$ sorghum } \\
\hline B963676 & $10.06 \mathrm{ab}$ & A1*FB963676/R931945 & $10.93 \mathrm{ab}$ \\
\hline B923296 & $9.86 \mathrm{abc}$ & B923296 & $10.91 \mathrm{ab}$ \\
\hline A1*FB963676/R931945 & $9.82 \mathrm{abcd}$ & B963676 & $10.76 \mathrm{abc}$ \\
\hline SC237-14E & 9.77 abcde & Buster & $10.55 \mathrm{abcd}$ \\
\hline Buster & 9.35 abcdef & SC237-14E & $10.46 \mathrm{abcd}$ \\
\hline SC170-6-8 & 9.30 abcdef & SC170-6-8 & $10.27 \mathrm{abcd}$ \\
\hline R9188 & 9.17 bcdefg & R9403463-2-1 & $10.17 \mathrm{abcd}$ \\
\hline R9403463-2-1 & 8.96 bcdefg & R9188 & $10.05 \mathrm{abcd}$ \\
\hline TAM422 & 8.84 cdefg & R931945-2-2 & $10.02 \mathrm{abcd}$ \\
\hline B35 & $8.54 \mathrm{cfg}$ & TAM422 & $9.68 \mathrm{bcd}$ \\
\hline Tx7000 & $8.54 \mathrm{cfg}$ & B35 & $9.61 \mathrm{bcd}$ \\
\hline R931945-2-2 & $8.41 \mathrm{fg}$ & Tx7000 & $9.40 \mathrm{~cd}$ \\
\hline Tx430 & $8.37 \mathrm{fg}$ & $\mathrm{Tx} 430$ & $9.29 \mathrm{~d}$ \\
\hline QL12 & $7.73 \mathrm{~g}$ & QL12 & $9.21 \mathrm{~d}$ \\
\hline
\end{tabular}

Values within a column followed by the same letters are not significantly different at the $5 \%$ level according to Duncan multiple range test

The presence of genotypic differences in TE of sorghum confirmed previous reports (Hammer et al., 1997; Henderson et al., 1998; Mortlock \& Hammer, 1999; Xin et al., 2009) and the ranking of genotypes was consistent with those previously published. For example, Hammer et al. (1997) reported that IS9710, SC237-14E and R9188 had TE $>7.0 \mathrm{~g} \mathrm{~kg}^{-1}$, whereas TAM422, Tx430 and QL12 had TE $<7.0 \mathrm{~g} \mathrm{~kg}^{-1}$. Consistent with this Tx430 and QL12 had the lowest TE (Table 6), whereas TAM422 also had low TE. Similarly, Xin et al. (2009) found that the TE of 2d genotypes PI391652 and PI584085 (8.9 $\left.\mathrm{g} \mathrm{kg}^{-1}\right)$ was significantly greater than that of Tx430 $\left(7.8 \mathrm{~g} \mathrm{~kg}^{-1}\right)$, whereas the TE of PI291382 (8.6 $\left.\mathrm{g} \mathrm{kg}^{-1}\right)$ was only marginally lower than that of PI391652 and PI584085. The consistency of TE values among genotypes between the current experiment and previously published 
Table 7: ANOVA of plant type and genotypic differences in photosynthesis capacity and conductance.

\begin{tabular}{|c|c|c|c|}
\hline \multirow{2}{*}{$\begin{array}{l}\text { Plant type } \\
\text { 2d sorghum }\end{array}$} & \multirow{2}{*}{$\begin{array}{l}\begin{array}{l}\text { Photosynthetic } \\
\text { capacity }\left(\mathrm{g} / \mathrm{m}^{2}\right)\end{array} \\
240 \mathrm{a}\end{array}$} & \multicolumn{2}{|c|}{ Conductance $\left(\mathrm{kg} / \mathrm{m}^{2}\right)$} \\
\hline & & & $24.89 \mathrm{a}$ \\
\hline $3 \mathrm{~d}$ sorghum & $200 \mathrm{~b}$ & & $22.71 \mathrm{~b}$ \\
\hline $\mathrm{CV}$ & 9.14 & & 13.32 \\
\hline Probability block & 0.0029 & & 0.0013 \\
\hline Probability species & $<0.0001$ & & $<0.0001$ \\
\hline Probability genotype & $<0.0001$ & & $<0.0001$ \\
\hline \multicolumn{4}{|l|}{$2 \mathrm{~d}$ sorghum } \\
\hline Ai4 & $270 \mathrm{a}$ & $\mathrm{Ai} 4$ & $31.32 \mathrm{a}$ \\
\hline PI391652 & $260 \mathrm{ab}$ & PI391652 & $27.18 \mathrm{ab}$ \\
\hline IS9710 & $250 \mathrm{abc}$ & IS9710 & $25.40 \mathrm{bc}$ \\
\hline PI656046 & 230 bcde & PI656046 & $23.32 \mathrm{bc}$ \\
\hline PI584085 & 210 defg & PI291382 & $22.55 \mathrm{bc}$ \\
\hline IS8525 & 200 fghi & IS8525 & $22.47 \mathrm{bc}$ \\
\hline PI291382 & 190 ghi & PI584085 & $21.97 \mathrm{bc}$ \\
\hline \multicolumn{4}{|l|}{$3 \mathrm{~d}$ sorghum } \\
\hline A1*FB963676/R931945 & $240 \mathrm{bcd}$ & R931945-2-2 & $25.27 \mathrm{bc}$ \\
\hline B963676 & 240 bcde & QL12 & $24.97 \mathrm{bc}$ \\
\hline B923296 & $230 \mathrm{cdef}$ & A1*FB963676/R931945 & $23.86 \mathrm{bc}$ \\
\hline R931945-2-2 & 210 defgh & B963676 & $23.10 \mathrm{bc}$ \\
\hline SC170-6-8 & 200 efghi & B923296 & $22.95 \mathrm{bc}$ \\
\hline SC237-14E & 200 fghi & B35 & $22.07 \mathrm{bc}$ \\
\hline QL12 & $190 \mathrm{ghi}$ & SC170-6-8 & $21.83 \mathrm{c}$ \\
\hline Buster & 190 ghi & Tx430 & $21.45 \mathrm{c}$ \\
\hline B35 & 190 ghi & R9403463-2-1 & $20.91 \mathrm{c}$ \\
\hline R9188 & $190 \mathrm{ghi}$ & TAM422 & $20.82 \mathrm{c}$ \\
\hline TAM422 & $180 \mathrm{ghi}$ & R9188 & $20.55 \mathrm{c}$ \\
\hline R9403463-2-1 & $180 \mathrm{ghi}$ & Tx7000 & $20.30 \mathrm{c}$ \\
\hline Tx7000 & $180 \mathrm{hi}$ & SC237-14E & $20.29 \mathrm{c}$ \\
\hline $\mathrm{Tx} 430$ & $170 \mathrm{i}$ & Buster & $20.26 \mathrm{c}$ \\
\hline
\end{tabular}

papers indicates that genotypic differences in TE in the current experiment were reasonable, providing further confidence in the observed values.

\section{Effect of plant stature on TE}

Crop stature did not significantly affect TE, as $2 \mathrm{~d}$ and $3 \mathrm{~d}$ sorghum had on average a similar TE. TE_shoot was not significantly different between $2 \mathrm{~d}$ and $3 \mathrm{~d}$ sorghum which were 9.05 and $9.32 \mathrm{~g} \mathrm{~kg}^{-1}$, respectively and this small difference could be accounted for by the difference in root/shoot ratio, as TE_(total) was similar for $2 \mathrm{~d}$ and $3 \mathrm{~d}$ sorghum $\left(10.1 \mathrm{~g} \mathrm{~kg}^{-1}\right)$. This would suggest that the greater dry mass partitioning to roots of $3 \mathrm{~d}$ sorghum compared with $2 \mathrm{~d}$ sorghum could be a consequence of reduced sink size in the shoot, associated with shorter stems (Table 3). Although the inclusion of roots did not substantially alter the results for TE among sorghum genotypes, inclusion of roots in the calculation of TE may be particularly useful under abiotic stress, where increased partitioning to the root can be a consequence of poor seed set (van Oosterom et al., 2011). 
Genotypic differences in TE were predominantly associated with differences in photosynthetic capacity (Figure 1), rather than conductance (Figure 2). The role of photosynthetic capacity on TE differences among genotypes found in this study was consistent with previous studies of Hammer et al. (1997) and Xin et al. (2009). In addition to this mechanism, Mortlock and Hammer (1999) reported that genotypic differences in TE of sorghum were associated with conductance and with leakage of $\mathrm{CO}_{2}$ from the bundle sheath (Henderson et al., 1998).

\section{Implications of differences in TE on drought adaptation}

The present hybrids of cereal crops are close to a theoretical upper limit of harvest index (HI) of 0.5 (Hay, 1995). However, manipulation of pre-anthesis water use can affect actual HI irrespective of potential $\mathrm{HI}$, because post-anthesis water availability is the main factor affecting grain yield of cereals under post-anthesis drought stress (Turner, 2004). The results of this study indicate that genotypic differences in TE of sorghum are predominantly associated with photosynthetic capacity and less with leaf conductance.

Stay-green, the ability of a crop to retain green leaf area during grain filling under drought stress, has been associated with drought adaptation of sorghum (Borrell et al., 2000). Hence, it is possible that the expression of stay-green is associated with increased TE. Among the four $3 \mathrm{~d}$ sorghum genotypes known to exhibit the stay-green trait (Table 1), only one (B923296) had high TE in the present study. The other three genotypes (B35, R931945-2-2 and QL12) had below average TE. However, the three genotypes known to lack stay-green expression (R9403463-2-1, TAM422 and Tx7000) also had average or below average TE (Table 1). Hence, there was no apparent association between stay-green expression and TE. A likely explanation for this apparent contradiction is that drought adaptation can be achieved through a range of different mechanisms, including reduced pre-anthesis water use through either small plant size or early flowering (van Oosterom et al., 2011). The stay-green drought adaptation of QL12 is hence likely associated with its earliness (Borrell et al., 2000; van Oosterom, 2011), whereas for BTx642 (formerly known as B35) and R931945-2-2 this was associated with low tillering (Kim et al., 2010; van Oosterom et al., 2011). The current results thus indicate that plant size and TE might be two independent drought adaptation traits. This would allow breeders to combine these traits into a single genotype.

\section{CONCLUSIONS}

The transpiration efficiency of sorghum was not associated with plant height. Significant genotypic differences in transpiration efficiency were associated with differences in photosynthetic capacity, rather than conductance. The lack of association between transpiration efficiency and known expression of stay-green (which is linked to plant size) indicates that these are potentially independent mechanisms for drought adaptation.

\section{Acknowledgements}

The authors thank the Australian Development scholarships (AusAid) programme for providing the financial support and opportunity to study in Australia.

\section{REFERENCES}

Andrade F.H., Echarte L., Rizzalli R., Maggiora A.D. \& Casanovas M. (2002). Kernel number prediction in maize under nitrogen or water stress. Crop Science 42: 1173 1179 .

DOI: https://doi.org/10.2135/cropsci2002.1173

Balota M., Payne W.A., Rooney W. \& Rosenow D. (2008). Gas exchange and transpiration ratio in sorghum. Crop Science 48: 2361-2371.

DOI: https://doi.org/10.2135/cropsci2008.01.0051

Blum A. (2009). Effective use of water (EUW) and not water use efficiency (WUE) is the target of crop yield under drought stress. Field Crops Research 112 (2-3): 119-123. DOI: https://doi.org/10.1016/j.fcr.2009.03.009

Borrell A.K., Mullet J.E., George-Jaeggli B., van Oosterom E.J., Hammer G.L., Klein P.E. \& Jordan D.R. (2014). Drought of adaptation of stay-green cereals is associated with canopy development, leaf anatomy, root growth and water uptake. Journal of Experimental Botany 65: 62616263.

DOI: https://doi.org/10.1093/jxb/eru232

Borrell A.K., Hammer G.L. \& Douglas A.C.L. (2000). Does maintaining green leaf area in sorghum improve yield under drought? I. Leaf Growth and senescence. Crop Science 40: 1026-1037.

DOI: https://doi.org/10.2135/cropsci2000.4041026x

Chapman S.C., Cooper M., Butler D.G. \& Henzell R.G. (2000). Genotype by environment interactions affecting grain sorghum I. Characteristics that confound interpretation of hybrid yield. Australian Journal of Agricultural Research 51: 197-207.

DOI: https://doi.org/10.1071/AR99020

Eamus D. (1991). The interaction of rising $\mathrm{CO}_{2}$ and temperatures with water use efficiency. Plant, Cell and Environment 
14: $843-852$.

DOI: https://doi.org/10.1111/j.1365-3040.1991.tb01447.x

Forster P. \& Ramaswamy V. (2007). Changes in atmospheric constituents and in radiative forcing. In: Climate Change 2007: The Physical Science Basis (eds. S. Solomon, D. Quin, M. Manning, Z. Chen, M. Marquis, K.B. Averyt, M. Tignor \& H.L. Miller), pp. 133-234. Cambridge University Press, Cambridge, UK.

Geetika G., van Oosterom E.J., Georg-Jaeggli B., Mortlock M.Y., Diefel K.S., McLean G. \& Hammer G.L. (2019). Genotypic variation in whole-plant transpiration efficiency in sorghum only partly aligns with variation in stomatal conductance. Functional Plant Biology 46: 1072-1089. DOI: https://doi.org/10.1071/FP18177

George-Jaeggli B., Jordan D.R., van Oosterom E.J. \& Hammer G.L. (2011). Decrease in sorghum grain yield due to the $d w 3$ dwarfing gene is caused by reduction in shoot biomass. Field Crops Research 124: 231-239.

DOI: https://doi.org/10.1016/j.fcr.2011.07.005

Hammer G.L., McLean G., Chapman S., Zheng B., Doherty A., Harrison M.T., van Oosterom E. \& Jordan D. (2014). Crop design for specific adaptation in variable dry land production environments. Crop and Pasture Science $\mathbf{6 5}$ : 614-626.

DOI: https://doi.org/10.1071/CP14088

Hammer G.L. (2006). Pathways to prosperity: breaking the yield barrier in sorghum. Agricultural Science 19: 16-21.

Hammer G.L., Farquhar G.D. \& Broad I.J. (1997). On the extent of genetic variation for transpiration efficiency in sorghum. Australian Journal of Agricultural Research 48: 649-655.

DOI: https://doi.org/10.1071/A96111

Hay R.K.M. (1995). Harvest index: a review of its use in plant breeding and crop physiology. Annals of Applied Biology 126 (1): 197-216. DOI: 10.1111/J.1744-7348.1995.tb05015.x

Henderson S., Von Caemmerer S., Farquha G.D., Wade L. \& Hammer G. (1998). Correlation between carbon isotope discrimination and transpiration efficiency in lines of $\mathrm{C} 4$ species Sorghum bicolor in the glasshouse and the field. Australian Journal of Plant Physiology 25: 111-123.

DOI: https://doi.org/10.1071/PP95033

Kim H.K., van Oosterom E., Dingkuhn M., Luquet D. \& Hammer G. (2010). Regulation of tillering in sorghum: environmental effects. Annals of Botany 106(1): 57-67. DOI: https://doi.org/10.1093/aob/mcq079

Lobell D.B., Roberts M.J., Schlenker W., Braun N., Little B.B., Rejesus R.M. \& Hammer G.L. (2014). Greater sensitivity to drought accompanies maize yield increase in the US Midwest. Science 344: 516-519.

DOI: https://doi.org/10.1126/science.1251423

Manschadi A.M., Christopher J., de Voil P. \& Hammer G.L.
(2006). The role of root architectural traits in adaptation of wheat to water limited environments. Functional Plant Biology 33: 823-837.

DOI: https://doi.org/10.1071/FP06055

Mortlock M.Y. \& Hammer G.L. (1999). Genotype and water limitation effects on transpiration efficiency in sorghum. Journal of Crop Production 2: 265-286.

DOI: https://doi.org/10.1300/J144v02n02_11

Passioura J.B. \& Angus J.F. (2010). Improving productivity of crops in water limited environments. Advances in Agronomy 106: 37-75.

DOI: https://doi.org/10.1016/S0065-2113(10)06002-5

Polley H.W., Johnson H.B., Mayeux H.S., Brown D.A. \& White J.W.C. (1996). Leaf and plant use efficiency of $\mathrm{C}_{4}$ species at glacial to elevated $\mathrm{CO}_{2}$ concentrations. International Journal of Plant Science 157(2): 164-170.

Sinclair T.R. \& Ludlow M.M. (1986). Influence of soil water supply on the plant water balance of four tropical grain legumes. Australian Journal of Plant Physiology 13: 329341.

DOI: https://doi.org/10.1071/PP9860329

Tanner C.B. \& Sinclair T.R. (1983). Efficient water use in crop production: research or research? In: Limitations to Efficient Water Use in Crop Production (eds. H.M. Taylor, W.R. Jordan \& T.R. Sinclair), pp. 27. American Society of Agronomy, Madison, WI, USA.

Turner N.C. (2004). Agronomic options for improving rainfalluse efficiency of crops in dryland farming systems. Journal of Experimental Botany 55: 2413-2425.

DOI: https://doi.org/10.1093/jxb/erh154

Vega C.R.C., Andrade F.H. \& Sadras V.O. (2001). Reproductive partitioning and seed set efficiency in soybean, sunflower and maize. Field Crops Research 72: 163-175.

DOI: https://doi.org/10.1016/S0378-4290(01)00172-1

van Oosterom E.J., Borrell A.K., Deifel K.S. \& Hammer G.L. (2011). Does increased leaf appearance rate enhance adaptation to post-anthesis drought stress in sorghum. Crop Science 51: 2728-2740.

DOI: https://doi.org/10.2135/cropsci2011.01.0031

van Oosterom E.J. \& Hammer G.L. (2008). Determination of grain number in sorghum. Field Crops Research 108: 259-268.

DOI: https://doi.org/10.1016/j.fcr.2008.06.001

Xin Z., Aiken R. \& Burke J. (2009). Genetic diversity of transpiration efficiency in sorghum. Field Crops Research. 111: 74-80.

DOI: https://doi.org/10.1016/j.fcr.2008.10.010

Yang Z., Hammer G., van Oosterom E., Rochas D. \& Deifel K. (2010). Effects of pot size on growth of mazie and sorghum plants. In: 1st Australian Summer Grains Conference (eds B. George-Jaeggl \& D.J. Jordan). Gold Coast, Australia, 21-24 June. 